\title{
Exploring the future of innovation diplomacy
}

\author{
Jos Leijten ${ }^{1}$ \\ Received: 28 July 2017 / Accepted: 4 December 2017 / Published online: 22 December 2017 \\ (C) The Author(s) 2017. This article is an open access publication
}

\begin{abstract}
Science diplomacy links the two policy domains of foreign affairs and science policy. Competitive thinking and the ways in which this affects global challenges are now putting the globalisation trends in science, technology and innovation under pressure. Rising populism adds to the growth of de-globalisation politics. In an increasingly knowledge driven world this leads to changes in the roles of diplomats. Their focus has already shifted from relatively neutral scientific collaborations to the technology and innovation interests of their home-countries. What are likely future developments of the field of science, technology and innovation diplomacy? The paper explores the future roles and development of innovation diplomacy as the outcome of interactions between the evolving characteristics of science, technology and innovation on the one hand and of international relations and foreign policies on the other. It is explorative, because there is no research tradition on which it can build and requires bringing together insights from several disciplines in new combinations. Trends in the fields of science, technology and innovation and in the field of international relations (including changes in the mechanisms and institutions for global governance) will be discussed. Together these drivers provide a framework through which potential futures of innovation diplomacy can be explored.
\end{abstract}

Keywords innovation diplomacy $\cdot$ science diplomacy $\cdot$ technology policy $\cdot$ knowledge economy $\cdot$ foreign policy $\cdot$ international relations $\cdot$ foresight $\cdot$ innovation systems

\section{Introduction}

\section{From science diplomacy to innovation diplomacy}

Science diplomacy is often conceived as the use of the "soft powers" of scientific collaboration to smoothen the political relations between two or more nations. It has become common to refer to this conceptualisation of science diplomacy as "science for diplomacy", which must be distinguished from "diplomacy for science", which refers to establishing scientific collaboration between two or more nations with the goal to address common problems (e.g. a joint space programme, fresh water shortages or climate change) [1].

Many, if not all, developed nations have special offices in their foreign services, which are responsible for science diplomacy actions. In organisational terms, it can be anything from a dedicated attaché in embassies to rather independent offices,

Jos Leijten

josleyten@gmail.com

1 Joint Institute for Innovation Policy (JIIP), Pleinlaan 9, 1050 Brussels, Belgium which are set up jointly with knowledge institutions and/or business.

Both the concept of science diplomacy and the role of the foreign services dedicated to science diplomacy are changing. With the rise of the knowledge economy or, to put it differently, with the growth of the role of knowledge as a factor in economic prosperity of countries, knowledge has become an increasingly important issue in the relations between nations. In a long process, the concept of knowledge has changed and broadened: from scientific knowledge, to technology (including issues of ownership and how technological knowledge is embodied in products and services), to the capacities to increase opportunities for innovation (social and economic value creation through new goods, services and systems).

This change is also visible in name-changes of the science diplomacy offices. In the case of the Netherlands the name of the science attachés in embassies changed in the 1990's to "science and technology attaché" and now they are called "innovation attaché". Other countries have implemented similar name-changes for their science diplomacy services.

Due to the growing importance of innovation in regional, national and foreign policies, the objectives and practices of 
science diplomacy are changing. Traditionally science diplomacy has had a focus on collaboration, but with the growing importance of knowledge driven innovation as a growth factor in the economy, competitive thinking is becoming more influential the field. Innovation policy, with its orientation at strengthening a countries' or region's innovation system, has - by definition - strong competitive elements. ${ }^{1}$

Over the past decades, the growth of knowledge-based innovation has gone together with processes of globalisation in business (global value chains and networks). ${ }^{2}$ Just as science, innovation has become global, e.g. through global technology platforms and innovation networks or the need to integrate complex systems of global trade and supply. But globalisation faces increasing criticism, which changes also the way in which nations deal with international competitive relations. And it changes the mission and roles of (innovation) diplomats.

This paper aims to highlight potential future directions for science, technology and innovation diplomacy, with a focus on innovation. In no way it may be seen as a full foresight study. It outlines a few approaches, which appear to be useful to unravel the complexity of the issue and make it fit for a more thorough foresight approach. ${ }^{3}$ The paper ends with a paragraph indicating a few issues which likely will appear in such an exercise.

Implicitly it also raises and tries to answer the question whether it is useful to talk about something like "innovation diplomacy". Such talk about "innovation diplomacy" is of very recent date and mostly exploratory. There is no generally accepted meaning of the term and there are no established practices (see for example [3-5]).

\section{Key concepts}

There is no widely used definition of science diplomacy, but there is wide agreement that science diplomacy is at the nexus of science policy and foreign affairs. Hence the following Wikipedia definition is appropriate: "Science diplomacy is the use of scientific collaborations among nations to address common problems and to build constructive international partnerships." 4 The collaboration may be directed towards common science and technology goals (diplomacy for science), but may also serve broader political purposes like building mutual trust (science for diplomacy). The use of these terms has become common since the 2010 joint conference

\footnotetext{
${ }^{1}$ It is probably right to say that competition and power always have been part of the set of drivers for science diplomacy. But with the growth of knowledgebased competition diplomatic actions have become more diverse. Seeking collaboration is one of the instruments in a much broader set.

${ }^{2}$ For an overview see: [2]

3 This will be the topic of further work in the EL-CSID project.

${ }^{4}$ https://en.wikipedia.org/wiki/Science_diplomacy. Accessed 9 September 2017.
}

of the American Association for the Advancement of Science and the Royal Society [1]. The term "science in diplomacy" was reserved for the use of science to improve the diplomatic service itself.

“(...) innovation diplomacy encompasses the concept and practice of bridging distance and other divides (cultural, socioeconomic, technological, etc.) with focused and properly targeted initiatives to connect ideas and solutions with markets and investors ready to appreciate them and nurture them to their full potential" [6]. More than science diplomacy it is linked to what is sometimes called economic diplomacy with its focus on building national gains in trade, investment, technology, etc. by diplomatic means. Following the above categorisation, innovation diplomacy should mainly, but not exclusively, be seen as diplomacy for innovation. It is closely linked to, or part of, trade and foreign economic policy.

This paper mostly uses the term innovation diplomacy, following a growing practice in public policy. It includes science and technology diplomacy. But in some cases, reference is made to science, technology and innovation (STI) diplomacy, to stress the different constituting elements. The future of innovation diplomacy is the outcome of interactions between the evolving characteristics of STI on the one hand and of foreign relations and foreign policies on the other. And this also encompasses the changing configuration of actors involved. Thus, a foresight perspective on innovation diplomacy should build on the future-oriented views of these two constituting elements.

The basic premises for this paper are that the growing importance of innovation and innovation policies in foreign relations will drive a number of changes:

- It brings new issues to the domain of science diplomacy, which drives the change to innovation diplomacy. The importance of national economic interests in the field is growing and puts issues like trade in high tech products, IP ownership and protection, and standardisation on the foreign policy agenda.

- It leads to changing stakeholder configurations. Companies and their representative organisations and local/regional public bodies are becoming increasingly important players in the domain of foreign policy.

- It leads to changes in the set of policy instruments and working methods relevant for STI diplomacy. A wide range of economic and social policy instruments relating to economic power is added to the field.

In the period of knowledge-based economies and societies, the level of scientific and technological capacities of nation states seems to critically determine their global status. According to Miremadi [7], innovation diplomacy is a form of diplomacy, which is part of a nations' innovation policy. Innovation diplomacy is the use of the full spectrum 
of tools of the state to achieve its (national) innovation interest in the global geopolitical arena. It involves the use of diplomacy to facilitate innovation and the use of innovation to improve the relations between countries. Theoretically innovation diplomacy should build on and/ or combine the fields of international relations (with its orientation on power) and innovation policy (with its orientation on economic opportunities and learning).

Diplomacy for innovation is wedged between two extremes of (international) political economy. On the one hand, there is the neo-liberal theory that - in the long run - all countries benefit from free exchange of knowledge and capital as the key means of production in advanced economies. Growth in one place brings growth in other places as well. Starting point is good jobs, quality of life and economic growth for all countries. The international side of this must be realised mostly through bilateral and multilateral agreements, alliances and collaboration. On the other hand, there are short-term self-interest driven approaches focusing on protection of national companies, markets and employment. The policies may include import taxes and other means to protect markets and employment. Between these two extremes, innovation systems' thinking helps to recognise a series of processes and developments, which guide the development of diplomacy for innovation. Before this framework is presented and discussed, this paper will, in the next paragraph, describe some experiences and practices of innovation diplomacy.

\section{Experiences and policy actions}

\section{Early examples of innovation driven by diplomacy}

The connection between diplomacy and innovation is not new. The speed with which Asian Tigers like Taiwan and South Korea developed from 1960 onward was the result of deliberate diplomatic actions to stimulate innovations, complemented by strategies of multi-national companies seeking advantages of a well-educated but relatively cheap labour force. After a Japanese occupation, the Second World War, the rise of communism in China and the Korean War (1950-1953), South Korea was left with a destroyed infrastructure and economy. Taiwan was only slightly better off under Kuomintang military rule after the Peoples Republic of China was established on the mainland (1949).

In the following Cold War period, the US, Japan and Western Europe had a clear interest in helping to build strong economic and politically stable nations in East Asia. In South Korea and Taiwan foreign aid proved to be a useful instrument, especially when combined with investments in industry. ${ }^{5}$ Most of the investments in industry were made possible through the soft loans mechanism. Most of the foreign direct investment over the period 1962-1982 came from Japan (close to 50\%), followed by the USA (around 30\%) and the Netherlands with 7.4\% [8]. The development of Taiwan followed similar patterns. The development in both countries typically began with a focus on import substitution industries, soon to be followed by building capacity in exporting industries, often accompanied by large export subsidies. South Korea followed a strategy of moving from import substitution to exporting industries in a broad range of sectors, including automotive, machinery, textiles, pharmaceuticals and of course consumer electronics. Taiwan benefited from early foreign direct investment from toy-maker Mattel and other US companies already in the 1960 's. But from 1980 onwards it shows a stronger focus on high-tech industries. "One example of the business-government collaboration was the entry of Taiwan's firms into the personal computer market, which began with a copy of Apple II in 1981 (...). And an IBM PC based on Intel 8088. (...). When IBM introduced its PC/AT in 1984, Taiwan's clone computers were on the market by the following year [9]."

The movement from import substitution to exporting industries was in both countries accompanied by building a massive R\&D capacity in the 1960's and 70's. Taiwan's Industrial Technology Research Institute (ITRI) is now one of the larger industrial research and technology organisations in the world. South Korea has built a number of more focused research organisations. These research institutions were instrumental for the next phase of development: innovation driven companies targeting global markets. These companies and the research organisations put the two countries high in the list of knowledge driven economies.

Despite all the foreign aid, which the two countries received to build economies that could withstand the threats and seductions of communism, their present status must not be seen as a direct result of diplomatic actions. The combination of international political interests, which translated into foreign aid, the interests of a larger number of transnational companies, which translated into foreign direct investment, and a relatively consistent national economic policy, together led to the success of Taiwan and South-Korea. It allowed a

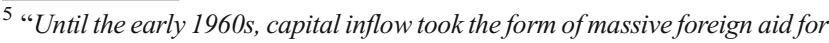
relief and rehabilitation of the economy. By the mid-1960s the concessional aid was phased out, gradually replaced by soft loans in limited amounts. In addition to the loans channelled through such donor agencies as USAID, the Japanese Overseas Cooperation Fund, the World Bank, and the Asian Development Bank, a growing share in loans took the form of supplier credit from the American or Japanese export-import banks. The real break in financing avenues for Korea came with the conclusion of the Japan-Korea Normalization Treaty in 1965. Korea could use its Property Claim Funds (war reparations) in establishing basic industrial and communication infrastructure [8]."
} 
transformation of the economy as a whole, and the growth of innovative companies, which develop new products, new services and new working methods.

\section{The growing role of innovation in diplomacy: the evidence}

Most of the evidence about science diplomacy is anecdotal or incidental. A well-known recent example is the story that the two key negotiators in the nuclear deal with Iran had been together in Massachusetts Institute of Technology (MIT) and could work out the deal based on mutual trust [10]. Another example is the recently opened Sesame synchrotron in Jordan, in which scientists from Iran, Israel, Jordan, Cyprus, Egypt, Pakistan, Turkey and the Palestinian Authority collaborate. In both cases the scientific collaboration may lead to political benefits.

The question that we want to address here is how diplomacy and diplomatic services are increasingly dealing with issues of innovation and innovation policy. A brief look at some indirect evidence might be useful.

A first indication is the growth of the number of publications about innovation diplomacy and more specifically in the number of advisory reports to governments. A simple Google search on "innovation diplomacy" shows that the concept is of recent date. With very few exceptions, most publications are from 2005 or later, taking into account that the EL-CSID project from which this paper is a result contributes to the number of publications. The same is true for government advisory reports, such as in Spain, the Netherlands, Japan, UK and the European Union. [11-14]. These reports also provide insights into how the concept of "innovation diplomacy" is developing. International scientific, technological and innovation collaboration is important in each of the reports. But all advisory reports also recognise the importance of technology and innovation in the context of economic and competition policy. The Dutch report (AWTI) is probably most explicit about this in the following statement: "It is essential that the Netherlands takes care that science, technology and innovation (STI) and diplomacy reinforce each other to benefit from global opportunities and not to lose from competing nations." ${ }^{.6}$ In other words, STI collaboration needs to be seen in a context of growth and competition.

A second indicator of the growing role of innovation in diplomacy can be found in a number of new initiatives for academic courses, symposia and training sessions. The initiatives range from more general courses on "innovation in diplomacy" to rather specific "innovation diplomacy" (e.g. diplomacy for innovation) initiatives. The University of Leiden offers an example of the first. ${ }^{7}$ The MIT Innovation

\footnotetext{
6 Translation by author.

7 See: https://studiegids.leidenuniv.nl/courses/show/54829. Accessed 12 November.2017.
}

Initiative develops a course with a stronger focus on diplomacy for innovation. ${ }^{8}$ A variety of academic symposia and workshops can be added to this. Their topics also range from the future of diplomacy, via innovation in diplomacy to innovation diplomacy.

A third indicator is the growth in the number of STI personnel in the foreign services. The US sent the first person with the title of "science attaché" to its embassy in Berlin in 1898 with a mission to overturn protectionist measures against the import of American pork [16]. This not only marks the start of a specialist STI service in the foreign services, but it also shows that right from the start the mission of this service was much broader than establishing scientific relations to ease the pursuit of political goals. In this case the economic policy goals were obvious. Several European countries started to build a network of science attachés at their embassies in selected countries after the Second World War. The main role of these services was to follow potentially interesting developments in science, to inform their home base and to inform their host-country. Following and informing about technological developments soon became part of their tasks. The job title of the Netherlands services was "technical-scientific attaché". A few years ago, it was changed into "innovation attaché". The main role of the Dutch innovation attaché is to support the competitiveness of the Netherlands, mainly through signalling and facilitating opportunities for R\&D collaboration and for international collaborative innovation. The Dutch Innovation Attaché Network now has 20 offices around the world. Other countries followed similar paths. For example, the UK Science and Innovation Network is currently present in over 30 countries and employs close to 100 diplomats. They want to make an impact by providing commercial benefits to the UK, by supporting UK research, influencing policy, and helping to tackle global challenges.

\section{Institutions for global governance and innovation}

Another way of finding evidence of a growing role of innovation in diplomacy is to look at how innovation and innovation-related issues are entering the agendas of the institutions of global governance. The following covers a few important lines of action in global governance and more specific in intergovernmental organisations, but is far from a complete overview.

The World Trade Organisation (WTO) is one of the most influential intergovernmental organisations with wide global membership (more than 160 countries). It operates as a permanent platform for negotiation about the rules and regulations of international trade. Innovation has become an important topic for the WTO, because innovation leads to new

\footnotetext{
${ }^{8}$ See: https://innovation.mit.edu/education-practice/affiliate-programs/ innovation-diplomats/. Accessed 12 November 2017.
} 
products, new services and new ways of organising their production. In many cases innovations, almost by definition, disrupt existing patterns of trade, pushing old products and services out of the market and/or change the place of their production. The prime innovation related topic on the WTO agenda is Intellectual Property Rights (IPR), negotiated under the heading of Trade Related aspects of Intellectual Property Rights in the TRIPS Council. The rules under which IPR are granted and protected are an important part of innovation policies. In TRIPS the WTO works closely together with the World Intellectual Property Organisation (WIPO), a selffunding United Nations agency. Next to their role in safeguarding IPR as one of the important drivers of innovation, these organisations face a number of challenges, which are directly related to the development of innovations. Examples are the debates about how current intellectual property rules offer opportunities for the pharmaceutical industry to develop and trade medicines at such a cost that they become unaffordable for low income countries [46], or how they create barriers for access to green technologies which countries may need to fulfil their commitments under the 2015 UN Paris Agreement on Climate Change. Other innovation related topics, which appear on the WTO agenda, are for example the development of global value chains [47] and the consequences of how innovation is increasingly agglomerated in so called innovation hubs or clusters. Interestingly, digitization, which is one of the key technologies driving innovation, with a profound impact on trade and trade relations, is so far only a minor topic in the WTO.

Other international governance bodies like UNIDO, the United Nations Industrial Development Organisation and the International Labour Organisation (ILO), a tripartite agency of the UN, which includes governments, employers- and workers-organisations, however, do deal with digitization. Both organisations try to come to grips with the potential impact of advanced manufacturing and automation on issues such as (un-)employment, gender and youth, to advance social justice. In those organisations innovation and the impact of new technologies has become an important topic.

International bodies that directly deal with innovation are, for example, the International Telecommunications Union (ITU), the Institute for Electrical and Electronics Engineers (IEEE) and the International Standards Organisation (ISO). ${ }^{9}$ Negotiations about standards may at first sight seem rather technical, but in many cases, they also involve considerable commercial interests. The companies behind these commercial interests are often backed by their national governments, when it comes to negotiating about competing standards. A

\footnotetext{
${ }^{9}$ This is just a small sample of important standards bodies. They are very different in terms of governance, mission and tasks. The ITU is an intergovernmental UN agency. ISO brings a wide diversity of national standards organisations together. IEEE is a membership based professional organisation.
}

fairly recent example is the backing of WIMAX (a wireless broadband internet standard) by the South Korean government between 2005 and 2010. This backing involved considerable international lobbying for WIMAX. Already in 2011 later it became clear that other standards were going to prevail [17]. China is often blemished for protectionist measures, such as the so far not very successful attempt to develop and require its own mobile Internet standard. But it is not only commercial interests, which are important in the standards negotiations. Sometimes political and cultural interests enter into the negotiations as well. For instance, in the early days of computing there have been long discussions about the use of French or English terms for some components and processes, with no other purpose than defending the French language. The interest to protect the French language is still strong [18], but less influential in international standardisation bodies.

A special case of linkages between innovation and diplomacy concerns military technologies. The diffusion (proliferation) of military technologies by trade, collaboration or other means has always been a point of concern. Enemies and potential enemies should be banned from having access to certain critical technologies. Globalisation of industry, and not in the least of the high-tech industries which are heavy users of critical technologies, is a point of growing concern. The development of global value chains leads to interdependencies between firms in widely diverse countries, which often require the exchange of technological knowledge. Especially since the rise of digital technologies it has become very difficult to monitor and control the diffusion of strategic technologies. In the 1980's the term "dual use technologies" was used for civil technologies, which could also be applied in military environments. Most industrial countries now have taken measures to control the diffusion of specified dual-use technologies. More than 40 nations from around the world have joined the socalled Wassenaar Arrangement, which lists critical weapons and dual use technologies, which should not be exported. But more importantly, the Wassenaar Arrangement requires the participants to report their transfers and their denial of transfers of arms and dual use technologies to destinations outside the arrangement on a regular basis. ${ }^{10}$

Next to all the organisations listed above there are many more who deal to a greater or lesser extent with the development and impacts of innovation at an international scale. To name just a few: the World Bank, the International Monetary Fund (IMF), the Asian Development Bank, the Organisation for Economic Cooperation and Development (OECD), the G20 and the World Economic Forum (WEF). The Intergovernmental Panel on Climate Change (IPPC) is an interesting case, not only because it has laid the scientific foundations for addressing one of the major societal challenges of our times, but also because it tells lessons about how STI

\footnotetext{
${ }^{10}$ See: http://www.wassenaar.org/. Accessed 12 November 2017.
} 
policies and foreign policies need to come together over a longer period of time to create conditions for solving such complex challenges [19]. The governance of these organisations may be very diverse, but they all function on a regular basis as a platform to inform, to negotiate, to monitor, to fund, etc. The OECD and the World Economic Forum (WEF) ${ }^{11}$ have gained considerable importance because of their open approach to building a shared vision.

\section{What are the shaping factors of innovation diplomacy?}

The actual shape of science, technology and innovation diplomacy is the outcome of two factors. The first is related to developments in science, technology and innovation. The second is related to developments in international relations. Together these two factors shape the international STI policies of nations. The EU RISE group [11: 108] concludes: “(..) one should limit the use of the concept (science diplomacy) to the policies and practices that involve both S\&T policy and foreign policy."

The following two paragraphs briefly describe trends in each of the factors and a third paragraph explores the consequences for STI policies.

\section{Changes in science, technology and innovation}

Trends in the development of science, technology and innovation will be described along a couple of dimensions:

1. Increasing complexity

2. Increasing collaboration and openness

3. Growth of knowledge society

4. Agglomeration and globalisation

The output of science, technology and innovation has been growing fast over the past decades. At the same time STI dealt with increasingly complex phenomena (see for instance [15]). The scientific problems of today, whether in life sciences (e.g. cancer research, bio-diversity, healthy foods), computer science (e.g. artificial intelligence, robotics), management sciences (e.g. logistics and supply networks), earth sciences (e.g. climate change) or materials (e.g. nanotechnologies), all have to deal with complex systems of interaction between many different factors. In the case of large living systems like cities and natural or social ecosystems the complexity is even larger. Research and technology development require an increasingly wide range of knowledge inputs. Multidisciplinary teams work on such complex problems. Gibbons and others have labelled these context-driven, problem-focused and

${ }^{11}$ The WEF is a non-profit private international organisation under Swiss law. interdisciplinary practices as Mode 2 research [20]. It leads to increasing scale and scope in research and technology development [21]. It may be expected that this trend will continue or even will be reinforced in the coming decade.

An important impact of this increasing scale and scope is the growth of the need to collaborate, with other researchers, with other research organisations and with companies that may own an essential part of the knowledge inputs which are needed to develop new products, services and systems. It has led to the concepts of "collaborative innovation" [22] and of "open innovation" [23]. The European Union has embraced these concepts and has taken them as a guiding principle for their policies in research and innovation [11]. Growing competition between globally leading firms and nations may however also lead to barriers against international collaborative and open research and innovation. The rise of the Internet has given new meaning to somewhat older concepts of user involvement in research: the "wisdom of the crowd" (or "collective intelligence"), which found its origins in marketing, is now rapidly becoming a valuable input in many different types of research [24]. All these concepts also point to a broadening of the actor and stakeholder configurations and knowledge inputs in research, technology and innovation. The interactions thereof are sometimes described as triple helix (interaction between science, industry and government), quadruple helix (including the wider public or civil society), and even quintuple helix (referring to nature and environment as an independent source of knowledge) [25].

The term knowledge economy or knowledge society is mostly used to refer to the fact that after agricultural and industrial society the world has entered a phase in which growth and development has become highly dependent on advances in knowledge. Knowledge is usually conceived in a broad sense in this context, e.g. besides scientific and technological findings it also includes works of art, design and cultural expressions. But most important maybe, is the growth of information, which has been made possible by the ability to capture, transmit and analyse large amounts of data with the ever-increasing capabilities of ICTs. Information and knowledge have become recognised as very important productionfactors, although, since this recognition more than 50 years ago, there are debates about the ways to measure how important. For this paper, however, the consequences of the growing role of information and knowledge as a determining factor in economic and social growth, competition and power are central. The combination of the above-mentioned trend toward openness and collaboration on the one hand, and the role of information and knowledge for competition between companies and for power relations between countries on the other, brings information and knowledge to the centre of strategy and politics. This may concern, for instance, access to data and information, access to certain scientific and technological findings. It may include strategies and rules about 
participation in the relevant networks of stakeholders. It is safe to assume that such issues will grow in importance with the increase of the role of information and innovation.

The fourth trend in STI to be discussed here is the role of geography. Over the past five decades and longer, technological development has facilitated a geographical fragmentation of production processes at a global scale. Different parts of a production process take place in different countries around the world, taking advantage of specific beneficial conditions. In the second half of the last century labour costs have been a very influential factor in the fragmentation and changing distribution of production processes around the world. Following the distribution of production processes, larger multinational companies also started to distribute part of their $R \& D$ processes, to support their production processes or market development. In more recent years also access to advanced knowledge pools has been a driver for globalisation of R\&D [26]. Gradually, these globalisation processes have become subject of policy making and, more specific, of innovation policy. Politicians in the European Union and the USA have questioned the on-going globalisation and are seeking opportunities to bring production "back home" through applying new technologies [27]. At the same time, factors such as rising wages in industry in China and other countries, reduction of the need for (manual) labour through increasing automation, and a growing complexity and diversity of technology options leads to changes in the drivers for globalisation. Together this may give rise to new trends in the geography of production and of R\&D and innovation.A second element of the geography of production and R\&D, which needs to be discussed, is the tendency towards agglomeration. The capabilities to develop, manipulate and use knowledge and technology, their applications and resulting production processes are not evenly spread around the world [48]. They have a tendency to agglomerate in what are called clusters, innovation hubs or mega-regions. One of the reasons behind this is the above-mentioned scale and scope effect. There is a limited number of such hubs around the world. The actual numbers depend on the way clusters and hubs are defined and measured. And the hubs may be very different from each other. Silicon Valley is dominated by ICT services. A few regions in China are seen as "the factory of the world" in consumer goods (electronics, textiles, toys). Parts of Germany are the hub for advanced machinery. The importance of such hubs for innovation and economic growth is increasingly recognised by politicians. Policies to strengthen existing hubs or to build new ones, through supporting further collaboration between companies and knowledge institutions and/or through protectionist measures (e.g. by controlling the flow of knowledge outside of the cluster) are developing rapidly.

\section{Changes in foreign relations}

Compared to developments in science, technology and innovation, the development of foreign relations and foreign policy is much more fluent. And although things usually do not change from one day to the other, there are events, which lead to rather sudden turns in international relations. Examples are Russia taking over the Crimea, which led to sanctions on trade, finances, etc. Or the rise of Islamic radicalism, leading to increased security measures and border control in many countries. Or the growth of the number of African immigrants in Europe, leading to fierce political discussion within Europe and a growth of nationalism. Or the rise of China as a modern world economic power which feeds protectionism in Europe and the US. It seems to be impossible to capture these changes in a set of rather stable trends. But at the same time there is a consensus growing that we are moving towards a multipolar world, in which a small group of nations (e.g. USA, China, Russia, and Germany/France) is setting the scene, some with declining, some with growing power. Conflicts are becoming a regular phenomenon [28]. Thinking about the future of foreign relations and foreign policies must take account of at least two powerful driving forces.

The first driver is related to what is nowadays often called populism, and reflects the search for recognition, identity, status, safety and well being of people against a political and economic establishment [29]. Its political expressions lead to a growth of nationalism and protectionism in the relations between states and to tensions within states when different parts of the population, whether defined by religion, ethnicity, wealth, political background, etc., are seeking ways to pursue their interests. The result is an increasingly fragmented world, characterised by competition, protectionist measures, closed systems and a diminishing acceptance of common "rules of the game" in trade and innovation (e.g. intellectual property rules).

The second driver is related to the fact that global challenges will not disappear when self-interest is becoming a guiding force in politics. Natural disasters (including those related to global climate change) and their direct and indirect consequences such as starvation, migration, territorial conflicts, etc. will also lead to a need for humanitarian action in the future. World endangering acts of nations (or the lack thereof) will push other nations to act jointly to contain the threats (e.g. in the case of North Korea or piracy in the Gulf of Aden). In other words, there will be a wide range of global challenges, which will continue to move people and politics.

The two drivers could be seen as acting against each other, the first one driving a move toward more closed systems and the second one emphasising the continued need for joint action. Van Langenhove sees multilateralism 2.0 [30] as a potentially powerful governance mechanism in such an environment. It foresees alliances on specific topics of mutual interest, 
not just between nations at government level, but also between different stakeholder communities.

\section{Innovation policies and foreign relations}

Innovation policies (conceived as the set of policies used to increase innovation capabilities and opportunities) are mostly only indirectly related to foreign policies or foreign relations. In most countries innovation policies are seen as part of economic policy and, because of the link with knowledge (science, R\&D), often also as part of science and education policies. In a way, this also reflects the collaboration-competition duality, which characterises innovation policy. Innovation policy is usually conceived within nation contexts, as one of the key concepts "national systems of innovation", shows ${ }^{12}$ [31]. Apart from the comparison of national systems, the international dimension is still weakly developed in research and policy-making. This international dimension becomes most clearly visible in the linkages with trade policies. A nation can be very innovative and develop a wealth of new products and services, but it needs access to markets to benefit from these innovations. Very large home-markets can in principle sustain such a development, but scale and scope effects are pushing companies to seek markets in other nations or even globally. In a world, which is susceptible to conflict based on the two counteracting drivers in foreign relations, access to markets becomes a key factor in the international dimension of innovation policy. For several years, the Information Technology and Innovation Foundation (ITIF) publishes its annual "Worst Innovation Mercantilist Policies" report [32]. It defines innovation mercantilism as "a strategy that seeks to achieve prosperity by imposing protectionist and tradedistorting policies that tip market scales to expand domestic technology production." Examples of such strategies are:

- Forcing companies to transfer technology or setup research centres as a condition of market access (localisation policies),

- Issuing or threatening to issue compulsory licenses for cutting-edge drugs,

- Mandating local technical standards or certifications to ensure local production,

- Directly or implicitly supporting government-sponsored theft of intellectual property, especially over the Internet.

ITIF signals a general growth of such practices around the world. It shows that there are clear linkages between market access and innovation policies. In other words, innovation is becoming a growing topic in international trade and thus in foreign policy practices and trade negotiations.

\footnotetext{
${ }^{12}$ For a discussion of the concept see [31].
}

This kind of innovation related trade policies partly explain the rise of innovation diplomacy. But when taking a closer look, we find that there is more to innovation and innovation policy and that access to markets is just one of the elements which must be considered. The following paragraphs will propose an approach, which allows further detailing of the international dimension of innovation and innovation policy, and provides a framework for analysing the future of innovation diplomacy.

\section{A framework for analysing the future of innovation diplomacy}

While analysing the scarce literature which discusses the role of innovation in relation to foreign policy, two perspectives can be found which do help to analyse and discuss the future of innovation diplomacy. The first is, what could be called an action perspective, with a focus on what innovation diplomats do, in what circumstances and which resources they have. The second approach is taking a more analytical perspective, with a focus on how different elements of innovation policy may inspire and guide foreign policies, and, more specific, economic and trade policies. A third paragraph discusses the role of foresight or future-oriented analysis in relation to choices in technology and innovation focus.

\section{Action perspective}

The action perspective is quite common in the analysis of science diplomacy. For a large part, this is because most analysis is case-based. ${ }^{13}$ The diplomatic nature itself (e.g. operating in the political relations between countries), the diversity of the field and the possible actions, for a large part explain that a case-approach is favoured. But the action perspective, with its focus on the individual actor, may also help to structure the work of the diplomats. The following three factors are instrumental to the outcome of potential actions:

a) The (politically given) intention and the willingness to (re-)engineer mind-sets, attitudes and behaviour,

b) The capacities and resources (money, regulations) to start a dialogue with stakeholders and policymakers,

c) Acceptance by stakeholders and in relevant networks.

What a diplomat then actually can do within the boundaries which are given by the above three factors is developed by Nesta (formerly NESTA: National Endowment for Science, Technology and Arts). Based on 10 case studies from the practices of the UK Science and Innovation Network (SIN),

\footnotetext{
${ }^{13}$ Science \&Diplomacy, the Quarterly Publication of the AAAS Centre for Science Diplomacy, provides many illustrations of this approach.
} 
Nesta produced a guide with the aim to use it to train and inspire UK science and innovation diplomats. It focuses on four roles that an innovation diplomat can take when supporting innovation collaboration [33]:

a) Exploring and Informing: Understanding innovation systems, spotting opportunities and barriers for collaboration and communicating them to the relevant organisations.

b) Influencing and Promoting: Influencing policies to improve the wider conditions for collaboration with innovative UK companies (e.g. IPR regimes) and promoting UK organisations as collaborators and the UK as a destination for foreign technology-based investments.

c) Cultivating and Connecting: Building relationships with decision-makers, designing targeted events and workshops to spur new international partnerships, organising missions to familiarise researchers and companies with new opportunities, matching individuals / institutions / companies with appropriate international partners and acting as an international portal for the UK innovation system.

d) Activating and Scaling: Develop, co-develop or identify external resources to help secure and scale promising collaborations, find ways to help accelerate the commercialisation of research or diffusion of innovation and build international partnerships that transform global opportunities for innovative firms.

Nesta focuses its guide on collaboration. This is appropriate in the specific view of science and innovation diplomacy, which starts from the premise that sharing knowledge and collaboration will contribute most to increasing the opportunities for innovation. It will certainly be very helpful for many actions of the innovation diplomats. But it does give no guidelines for the more competitive approach of innovation, which is based in foreign trade and economic policy. Here an analytical approach of different aspects of innovation may help.

\section{Analytical perspective}

\section{Action perspective}

The linkages between innovation and trade are receiving attention in the literature [34-36]. The OECD report focuses on the following three linkages:

First, imports and foreign direct investment (FDI) as well as trade in technology serve as channels of technology diffusion. Second, imports, FDI and technology licensing contribute to intensifying competition, which can affect incentives for innovation. Third, exports can affect innovation as it serves as a learning opportunity and gives incentives for innovative activities [35].

Although this approach already provides more insights in the relations between trade, exports and innovation, the problem remains that it treats innovation (and technology diffusion) as a rather abstract category or black box. Following a few authors [7, 37] who have tried to overcome this problem, it is here proposed to use the "functions of innovation systems" approach [38] for a future-oriented analysis of innovation diplomacy. Hekkert et al. say there is a set of key processes that need to take place for an innovation system to develop. These key processes are called the 'functions of innovation systems' as these processes are required to be performed in the innovation systems. It is essentially these processes, which can be targeted by innovation diplomacy. Each of the functions can be used to build bridges between two or more (national) innovation systems. But they can also be the starting point for developing protective measures. So, the functions provide a useful taxonomy to structure the search for and mapping of potential innovation diplomacy actions.

The following Table 1 is an attempt to map potential innovation diplomacy actions in relation the innovation systems functions and their most relevant dimensions. In the first column, it follows the basic structure of the seven functions as outlined by Hekkert et al. [38] and further discussed in [39]. The second column provides further detail and interpretation of the functions, to build the linkage to examples of potential diplomacy actions in the third column. This interpretation is based on further details provided by Hekkert and his co-authors, and on Miremadi's analysis [7].

Table 1 and the given examples of issues for potential diplomacy actions show that this analytical perspective with its detailing of the functions of innovation systems helps to develop a more systematic approach to the identification and mapping of innovation diplomacy actions.

\section{Innovations perspective}

\section{Action perspective}

Foresight or Futures Studies and related methods such as ex-ante impact assessment and constructive technology assessment, are part of the standard toolbox of science, technology and innovation studies. The information such studies generate is usually intended to feed strategy and policy making processes. Expectations about the role of science and foresight in policy-making processes can be quite high: 
Table 1 Innovation system functions and potential innovation diplomacy actions

\begin{tabular}{|c|c|c|}
\hline Innovation System Function & Relevant Dimensions & Innovation Diplomacy Actions (examples) \\
\hline 1. Entrepreneurial discovery & $\begin{array}{l}\text { Capacity to turn potential of new knowledge, } \\
\text { technology, networks, and markets into } \\
\text { business opportunities. }\end{array}$ & $\begin{array}{l}\text { Support industry in development of (global) } \\
\text { innovation networks, value chains, etc. } \\
\text { Promote and protect national champion } \\
\text { projects and industries. }\end{array}$ \\
\hline 2. Knowledge development & $\begin{array}{l}\text { Institutions and resources for education, skills } \\
\text { development and research (universities, } \\
\text { research facilities). Including less formal } \\
\text { learning such as "learning by doing". }\end{array}$ & $\begin{array}{l}\text { Support international collaborative research } \\
\text { and education. } \\
\text { Support IPR. } \\
\text { Access to strategic research facilities. }\end{array}$ \\
\hline $\begin{array}{l}\text { 3. Knowledge diffusion } \\
\text { through networks }\end{array}$ & $\begin{array}{l}\text { Maximise the effects of new knowledge, } \\
\text { feed policy processes for standards } \\
\text { and regulation. }\end{array}$ & $\begin{array}{l}\text { Support development of an innovation } \\
\text { culture. } \\
\text { Develop strategy for inclusion/exclusion } \\
\text { (e.g. non-proliferation for security reasons). }\end{array}$ \\
\hline 4. Guidance of the search & $\begin{array}{l}\text { Selection of specific foci for investments in } \\
\text { STI. Building the long-term vision. Identifying } \\
\text { needs and wants. Priority setting. Mostly done } \\
\text { between different types of actors in a country, } \\
\text { region or hub. }\end{array}$ & $\begin{array}{l}\text { Identify potential collaborators and } \\
\text { competitor's strategies. } \\
\text { Develop position and strategy for } \\
\text { common or global challenges. } \\
\text { Develop vision and strategy } \\
\text { for national strengths. }\end{array}$ \\
\hline 5. Market formation & $\begin{array}{l}\text { Create or support (public) demand } \\
\text { (e.g. favourable tax regime, } \\
\text { innovative procurement). } \\
\text { Create a (protected) space for testing, } \\
\text { piloting and possibly niche markets. }\end{array}$ & $\begin{array}{l}\text { Strategies to improve access to foreign } \\
\text { markets for innovative products/services: } \\
\text { - Import/export tariffs } \\
\text { - Innovation mercantilism } \\
\text { - Room for experimentation } \\
\quad \text { (legal and regulatory conditions) }\end{array}$ \\
\hline 6. Resources mobilisation & $\begin{array}{l}\text { Capital availability in different stages of } \\
\text { innovation. Human resources } \\
\text { (including foreign specialists). }\end{array}$ & $\begin{array}{l}\text { - Access to Public Private Partnerships } \\
\text { - Exchange programs } \\
\text { - Special mobility and tax-rules for } \\
\text { knowledge workers. }\end{array}$ \\
\hline $\begin{array}{l}\text { 7. Creation of legitimacy; } \\
\text { fighting resistance to change }\end{array}$ & $\begin{array}{l}\text { Build coalitions. How to deal with vested } \\
\text { interests and frictions of transition? } \\
\text { Is new legal framework required? }\end{array}$ & $\begin{array}{l}\text { - Standards } \\
\text { - Policy consistency (e.g. GMOs) } \\
\text { - Responsible Research and Innovation rules }\end{array}$ \\
\hline
\end{tabular}

(...) scientists can play a major role by providing data and evidence that identifies challenges, advising on needed policy actions, and probing for innovative solutions. Science can additionally help monitor attempts to remediate global problems. The 2030 Agenda $^{14}$ thus allows researchers to not only deliver input but also increase the impact of such input [30].

But there is also wide awareness that the transfer of research results into the policy-making community is not without problems:

(...) the S\&T community faces several challenges, among them the delicate issue of how to translate research results into (global) policy. This is a matter not only of impact but also of power politics within the S\&T community. Indeed, scientific results are seldom straightforward, and the whole process of scientific progress is driven by debates and competing paradigms,

\footnotetext{
14 The United Nations sustainable development agenda.
}

complicating the task of influencing the policy-making realm. Here, conducting the necessary research is not sufficient in itself. Thereafter, results need to be disseminated and translated based on consensus through interactions with policy makers, a time-consuming endeavour for which scientists generally lack the training. Finally worth remembering is that states not only collectively control the multilateral system, they also largely control national S\&T systems through their funding policies for research [40].

The take-up of research findings in policy-making may be a lengthy and time-consuming process, certainly when they address major societal and political challenges [19]. This is also true for how specific innovations may become the subject of innovation policy. In general, governments have been reluctant to endorse specific innovations and the surrounding networks of firms and research centres. At the same time, the systems of generic research, technology and innovation policy inevitably supported national specialisations in research and in industry [41]. The 
financial crisis $(2007-\ldots$.$) , growing nationalism, pressing$ challenges such as climate change, and the increasingly competitive international environment together are pushing governments to make more explicit choices with regard to future technologies [42, 43]. Several countries have now anchored these current and near future specialisations into their national innovation strategies. For example, in the Netherlands, this is done via the so-called "top-sectors policy", an innovation strategy focusing on the ten most important sectors of the national economy. In France, a similar kind of strategic sectors support has become an explicit part of foreign policy. ${ }^{15}$ So, the choices made do not only guide national innovation policies, including R\&D funding, support for public-private collaboration in hub/clusters, or support for technology based start-up companies, but they will also guide foreign policies and thus innovation diplomacy.

Research and innovation policies will become closely linked to foreign security, economic and trade policies. A clear example is provided by recent developments in the European Union's strategy with regard to solar PV. Over the past decade European production of solar panels has, by and large, been lost to China. But European research and development specialisations in the field are being evaluated as quite high [44]. It creates the conditions in which the European Union is embarking upon a strategy to bring production of newer generations of solar technologies back to Europe. A direct consequence is that research collaboration with China in this field is no longer supported and that imports from solar panels produced in China are subject to higher import tariffs.

The quoted study [44] shows a number of other European specialisations (including a forecast for 2020). There are clear comparative specialisations in advanced manufacturing technologies, space, Internet of Things, transport, food and health. In none of these fields, however, the European international strategy is as clear as in the case of solar PV. On the contrary, the official policy is "open science, open innovation, open to the world", which may be described as naïve in the current global competitive environment [45]. Pressures to protect Europe's (future) knowledge and industrial assets are growing, not only directly from the industries involved, but also through the growth of nationalist sentiments in the wider population. And Europe is not the only place where these processes take place. The nationalist rhetoric in the USA under president Trump is much stronger. China has published its strategy to become world leader in a large number of technologies. These developments all

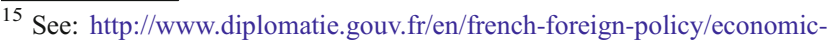
diplomacy-foreign-trade/supporting-french-businesses-abroad/strategicsector-support/. Accessed 12 November 2017
}

underpin our thesis that, next to the generic policies to raise innovation capacities, as discussed in the previous paragraph, the actual fields of technology and innovation, are part of the diplomat's battlefield.

\section{Conclusions and a view to the future}

With the changes in international relations since the end of the Cold War and with the growth of the role of knowledge in the economy and of the competition between firms and between nations, the concept of science diplomacy (conceived as the use of the soft powers of science to ease relations between countries) has lost much, but not all, of its meaning. Competition and trade have always played a role in international relations. Trade agreements (regulating the conditions of access to markets) have a history, which goes back to the Middle Ages or even before. The growth of the knowledge economy is pushing strategies and policies for knowledgebased competition to the centre of the scene, not only in national politics, but also in foreign policy. It makes it useful to talk about "innovation diplomacy", certainly when this encompasses science, technology and the diffusion thereof. It makes innovation a key topic in foreign economic, trade and security policies. This development is leading to a growing demand for multidisciplinary skills in the diplomatic services. An understanding of how innovation based competition works is required, which means understanding the functions of innovation systems, the strategic fields of science, technology and innovation, how they are produced (key-actors) and how their markets develop. The policy outcome will in most cases be a complex mixture of policies aiming at collaboration, at protecting and strengthening strategic interests and at building international coalitions and agreements to further joint interests. Facing increasing competition and growing nationalism/regionalism, one should beware of putting false hopes on what negotiations in the long-established bodies for global governance like the UN and WTO can achieve. But at the same time new opportunities for multilateral solutions may come from the growing involvement of new stakeholders in the international relations around innovation. Major cities and regions from around the world are meeting on a regular basis to discuss innovation strategies and experiences, thereby creating a new platform for developing informal and sometimes also formal shared visions and rules of behaviour.

There are several initiatives to use foresight as a mechanism to build shared visions in international relations. To mention just a few examples: UNESCO, UNIDO, OECD and WEF all have explicit units or projects for foresight. Private and non-profit organisations also take initiatives. For example, RAND has initiated the Mediterranean Foresight Forum and the Atlantic Council has its Foresight, Strategy and Risks Initiative. The international 
security situation brings technology and innovation into these initiatives. But also in the context of international social affairs the attention for innovation is growing, with topics such as the impact on labour markets and social security of automation, robotics and artificial intelligence. Foresight thus may become a valuable tool for innovation diplomacy, building on and broadening a strong tradition of technology foresight.

The actual possibilities and need for science diplomacy will depend on what will happen with the issues resulting from the interaction of developments in science, technology and innovation and in foreign relations that we discussed in this paper. One of the important questions will be if innovation diplomacy can play a role in uniting nations around a number of challenges which the world faces, such as climate change, population growth, water shortages, migration, etc. In these challenges, science, technology and innovation are important to work toward solutions. But so far, in none of them (not even on climate change after the Paris Agreement) a shared vision, let alone strategy, is in sight. Will multilateralism, with socalled variable geography solutions to different topics and in different sectors of the economy, be the solution? Can the future of health be developed in an international configuration, which is very different from the configuration in which fighting climate change is being developed? And finally, how will the position of Europe between the science and technology powerhouses of the US and China develop? Can Europe increase investments in $R \& D$ and innovation and remain a strong player in a number of key technologies and sectors of the economy? That will be the basis for the future of European innovation diplomacy.

Acknowledgements This paper has been written for the EL-CSID project which has received funding from the European Union's Horizon 2020 Research and Innovation programme under Grant Agreement No. 693799.

Publisher's Note Springer Nature remains neutral with regard to jurisdictional claims in published maps and institutional affiliations.

Open Access This article is distributed under the terms of the Creative Commons Attribution 4.0 International License (http:// creativecommons.org/licenses/by/4.0/), which permits unrestricted use, distribution, and reproduction in any medium, provided you give appropriate credit to the original author(s) and the source, provide a link to the Creative Commons license, and indicate if changes were made.

\section{References}

1. Royal Society and AAAS (2010) New Frontiers in Science Diplomacy. Navigating the changing balance of power. London. https://www.aaas.org/sites/default/files/New_Frontiers.pdf. Accessed 28 July 2017

2. van der Giessen A, Stolwijk C, Leijten J (eds) (2015) Can Policy follow the dynamics of global innovation platforms? 6CP, Delft. h t t p s://w w w. 6 c p. net/down 1 o a d s / 6 C P Canpolicyfollowthedynamicsof $\% 20$ globalinnovationplatforms final.pdf. Accessed 18 Dec 2017

3. Hormats R, Wessner C (2013) The road to an effective innovation diplomacy. HuffPost. https://www.huffingtonpost.com/ bob-hormats/the-road-to-an-effective-_b_3306749.html. Accessed 10 Oct 2017

4. Wilsdon J, Bound K, Saunders T (2013) Beijing's innovation diplomacy. The Guardian, 9 October https://www.theguardian. com/science/political-science/2013/oct/09/science-policy. Accessed 10 Oct 2017

5. Danilin I (2012) Diplomacy and Innovation: the idea comes first. Russia in Global Affairs, 7 October. http://eng.globalaffairs.ru/ number/Diplomacy-and-Innovation-The-Idea-Comes-First-15689. Accessed 10 Oct 2017

6. Carayannis EG, Campbell DFJ (2011) Open Innovation Diplomacy and a 21st Century Fractal Research, Education and Innovation (FREIE) Ecosystem. Building on the Quadruple and Quintuple Helix Innovation Concepts and the "Mode 3" Knowledge Production System. J Knowl Econ 2:327-372. https://doi.org/10. 1007/s13132-011-0058-3

7. Miremadi T (2016) A model for science and technology diplomacy. How to align the rationales of foreign policy and science. February/ SSRNWeb. http://papers.ssrn.com/sol3/papers.cfm?abstract_id= 2737347. Accessed 28 July 2017

8. Kim KS (1991) The Korean Miracle (1962-1980) revisited: Myths and Realities in Strategy and Development. Helen Kellogg Institute for International Studies, Working Paper 166

9. Hollingsworth DA (2007) The Rise, the Fall, and the Recovery of Southeast Asia's Minidragons. Lexington Books, Lanham

10. Bernstein A, King J, Perry R (2015) Editorial: MIT's Role in the Iran Nuclear Negotiations. MIT Faculty Newsletter 28(1), September/October

11. European Commission (2017) Europe's Future: Open innovation, Open Science, Open to the World. Reflections of the Research, Innovation and Science Policy Experts (RISE) High Level Group. Brussels

12. MOFA (2015) Advisory panel on science and technology diplomacy. Tokyo, May

13. AWTI (2017) Offensief voor Internationalisering van Wetenschap, Technologie en Innovatie. AWTI, Den Haag

14. EXTERIORES (2016) Report on Science, Technology and Innovation Diplomacy. Madrid

15. Bonaccorsi A (2007) The ERC: a contribution to society and the knowledge-based economy. Keynote speech at ERC Launch Conference. February 27-28, Berlin

16. Ciferri O (1987) For Science Attaches, it's Pinstripes, not Lab Coats. The Scientist, June

17. Goldstein P (2011) Broadcom acknowledges WiMAX's U.S. decline. FierceWireless, 12 August http://www.fiercewireless. com/wireless/broadcom-acknowledges-wimax-s-u-s-decline. Accessed 10 Oct 2017

18. Toor A (2016) France wants a new keyboard to protect its language. The Verge, 21 January. https://www.theverge.com/ 2016/1/21/10805562/france-change-keyboard-layout-azerty. Accessed 10 Oct 2017

19. Montalvo C, Leijten $\mathrm{J}$ (2015) Is the response to the climate change and energy challenge a model for the societal challenges approach to innovation? Contribution to the Forum: The Impact of Horizon 2020 on Innovation in Europe. Inter Econ 50(1):25-30. https://doi. org/10.1007/s10272-015-0521-7

20. Gibbons M, Limoges C,Nowotny H, Schwartzman S, Scott P, Trow M (1996) The new production of knowledge: the dynamics of science and research in contemporary societies. Sage, London

21. Vonortas $\mathrm{N}$ et al (2011) Economies of scale and scope at the research project level. Publications Office of the European 
Commission, Brussels. http://publications.europa.eu/resource/ cellar/fdb9ae6b-9fa6-4151-94d1-7057e4d32197.0001.02/DOC_1. Accessed 10 Oct 2017

22. Steinmueller W (2002) Collaborative Innovation. In: de la Mothe J, Link AN (eds) Networks, Alliances and Partnerships in the Innovation Process. Springer, Boston, pp 29-43

23. Chesbrough HW (2006) Open innovation. The new imperative for creating and profiting from technology. Harvard Business Press, Cambridge

24. Saunders T, Mulgan G (2017) Governing with collective intelligence. Nesta, London

25. Carayannis E, Campbell D (2012) Triple helix, Quadruple Helix and Quintuple Helix and how do knowledge, innovation and the environment relate to each other? Int J Soc Ecol Sustain Dev 1(1):41-69

26. Kinkel S (2015) Setting the scene: Global value chains, re-shoring activities, global innovation networks, and their impact on global innovation platforms. In: van der Giessen A, Stolwijk C, Leijten J (eds) Can Policy follow the dynamics of global innovation platforms? Papers from a 6CP Conference. 6CP, Delft pp 15-40

27. van der Zee F et al (2007) Delocalisation of EU Industry, Delocalisation and the challenge of structural adjustment. A review of policy options. The Network for European Techno-Economic Policy Support ETEPS AISBL, Brussels

28. Witt MA (2017) The future world order. Insead, 2 January. https:// knowledge.insead.edu/economics-finance/the-future-world-order5115. Accessed 28 July 2017

29. Meyer H (2017) Understanding the Populist Revolt. Social Europe 11, April

30. van Langenhove L (2010) The Transformation of Multilateralism Mode 1.0 to Mode 2.0. Global Pol 1(3):263-270

31. OECD (1997) National innovation Systems. OECD, Paris

32. Cory N (2016) The Worst Innovation Mercantilist Policies in 2016. ITIF, Washington

33. Nesta (2015) Innovation Policy Toolkit: Tradecraft for Innovation Diplomats. Nesta, London. https://www.nesta.org.uk/publications/ innovation-policy-toolkit-tradecraft-innovation-diplomats. Accessed 10 Oktober 2017

34. Aghion P et al (2017) The Impact of Exports on Innovation: Theory and Evidence. Harvard University. https://scholar.harvard.edu/files/ aghion/files/impact_of_exports.pdf. Accessed 28 July 2017
35. Kiriyama N (2012) Trade and Innovation. Synthesis Report. OECD Trade Policy Papers. OECD, Paris

36. Navas A, Sala D (2015) Innovation and trade policy coordination: The role of firm heterogeneity. World Econ 38(8):1205-1224

37. Iizuka M, Gebreeyesus M (2017) Using Functions of Innovation Systems to Understand the Successful Emergence of Nontraditional Agricultural Export Industries in Developing Countries: Cases from Ethiopia and Chile. Eur J Dev Res 29(2): 384-403. https://doi.org/10.1057/s41287-016-0004-0

38. Hekkert $\mathrm{M}$ et al (2007) Functions of innovation systems: A new approach for analysing technological change. Technol Forecast Soc Chang 4:413-432

39. Hekkert M (2010) The Challenge of Sustainable Innovation Policy. In: Elg L, Leijten J (eds) New economic ground for innovation policy. Cultivalibros, Bilbao, pp 97-116

40. Cuhls K (2015) Lessons for policy-making from Foresight in NonEuropean Countries. European Commission, Brussels

41. Block F, Keller MR (2011) State of Innovation: The U.S. Government's Role in Technology Development. Paradigm, Boulder

42. Elg L, Leijten J (2010) New economic ground for innovation policy. Cultivalibros, Bilbao

43. Mazzucato M (2013) The entrepreneurial state. Debunking public vs private sector myths. Anthem Press, London

44. Reiss T, Frietsch R, Schubert T, Kukk P, van de Velde E (2016) Study on EU Positioning: An Analysis of the International Positioning of the EU Using Revealed Comparative Advantages and the Control of Key Technologies. European Commission, Brussels

45. Leijten $\mathrm{J}$ (2017) Protectionism and nationalism versus open innovation: A challenge for Europe's innovation diplomacy. EL-CSID, 15 May. https://www.el-csid.eu/single-post/blognote8. Accessed 10 Oct 2017

46. WHO, WIPO, WTO (2013) Promoting Access to Medical Technologies and Innovation, Intersections between Public Health, Intellectual property and Trade. Geneva

47. WTO (2017) Global Value Chain Development Report 2017. Measuring and Analyzing the Impact of GVCs on Economic Development. International Bank for Reconstruction and Development/The World Bank, Washington

48. Florida R (2005) The world is spiky. The Atlantic Monthly, October 